This is a post-peer-review, pre-copy edited version of an extract/chapter published in "Revisiting the 'ideal victim': developments in critical victimology" Details of the definitive published version and how to purchase it are available online at: [insert URL link to Policy Press website here]

\title{
Creating Ideal Victims in Hate Crime Policy
}

Hannah Mason-Bish

\section{Abstract}

This chapter will suggest that problems over the perception of the nature of hate crime mean that often victims of disablist hate crime are overlooked. Developed partly through campaign group activism and high profile cases, hate crime has become a solid part of criminal justice policy and practice. The legal framework recognises different forms of crime motivated by prejudice or hostility towards victims based on their race, religion, sexual orientation, transgender identity and/or disability. However, this chapter will demonstrate that there are particular problems with the implementation of provisions related to disablist hate crime which can be understood by utilising Nils Christie's 'ideal victim' typology. Born out of an identity politics which sought recognition for the specific harms of hate crime, the development of policy has been shaped by sometimes simplistic perceptions of what it is to be victimised. These have often been framed around issues of stranger danger and attributing recognition to 'deserving victims'. This reliance on identity politics has often meant that victims of disablist hate crime are portrayed as weak and vulnerable, a situation which Christie suggests can contribute to anxiety and a questionable focus on the need for severe punishments. Fundamentally this chapter will show that Christie's ideal victim thesis is relevant today, with an increasing emphasis on identity politics which is used to demonstrate that victims are both 'deserving' and 'legitimate'.

\section{Introduction}

In July 2013 Bijan Ebrahimi was brutally murdered in Bristol, UK. The 44-year-old mentally disabled man, who had come to Britain as a refugee from Iran, had sought help from the police on a number of occasions because of the escalating harassment that he was receiving from neighbours. Members of the local community had accused him of being a paedophile after finding him taking photographs of young people who 
he had thought were vandalising his hanging baskets. He was arrested but quickly released due to a lack of evidence. Ebrahimi telephoned the police the day after his release from arrest, saying: 'My life is in danger. Right now a few of my neighbours are outside and shouting and calling me a paedophile. I need to see PC Duffy.' (Peachey, The Independent, 2015). But PC Duffy did not attend, or even speak to Bijan, characterising him as an inconvenience and a nuisance. The next day Lee James, a local neighbour, dragged Ebrahimi from his home and kicked him until he was unconscious. James was then joined by another neighbour who poured white spirit over Ebrahimi and set him on fire. James was eventually convicted of murder and sentenced to life in prison while Stephen Norley, who set Ebrahimi alight, received a 4-year custodial sentence. As a result of failings leading up to the murder, eighteen police officers involved in the case also faced disciplinary proceedings; two officers were given prison sentences for failing to protect Bijan.

The case presents a complex mix of factors which point towards the difficulties faced by victims of disablist hate crime, particularly those with mental disabilities or learning difficulties. In the above instance we see a criminal justice response which criminalises the victim (in that Ebrahimi was arrested on suspicion of paedophilic offences) and, once exonerated, fails to take the required action to protect a vulnerable person. Despite the repeated acts of hostility directed towards him, no prosecutions - including his eventual murder - were brought under the disability hate crime provisions. This case, as with others outlined in this chapter, illustrates a key area of concern to (disability) hate crime theorists: the arbitrary nature of criminal justice responses discerning between 'disability hate crime' and disabled persons being victims of (hate) crime. It would appear that the preference is to adopt the latter approach in a manner not fitting with other recognised forms of hate crime (in the UK, at least). In this chapter, an analysis of this differentiation invokes Christie's (1986) 'ideal victim' framework to assess how the construction of the victim is key to the ensuing response granted to them. In order to not conflate the two approaches, the terminology 'victims of disablist hate crime' will be adopted rather than 'disabled victims of hate crime'. This is to highlight the disablism of the hate crime perpetrator rather than disability of the victim which is to blame for the crime.

The extent to which victims of disablist hate crime - that is, people who have been targeted for victimisation as a result of disablism - are victimised, overlooked and 
underprotected is subject to a growing body of literature and research. There is wide ranging evidence of the scale of the problem of disablist hate crime. The Crime Survey for England and Wales indicated that the 2015-16 rate of 3,629 was a $44 \%$ increase on the previous year (Home Office, 2016). Qualitative research demonstrates the dehumanising features of disablist hate crime, with victims often experiencing degrading treatment by perpetrators but also so-called 'low level' abuse which can continue over months and years (Roulstone and Sadique, 2013, Sin, 2015). Reports such as Scope's 'Getting Away with Murder' (2008) or the European Human Rights Consortium's 'Hidden in Plain Sight" (2011) point towards how victims are ignored by the criminal justice system as well as by wider society. The common theme is that such violence is hidden, but also subject to systemic failures and institutional disablism. These barriers have real consequences for victims who then tend to normalise their experiences, thus not seek legal redress (Roulstone and Sadique, 2013; Thorneycroft and Asquith, 2017). This also has an international commonality in that jurisdictions with hate crime provisions find that disability is one of the categories least likely to be reported to police (Sherry, 2010; Levin, 2013).

Yet when using Nils Christie's typology of the ideal victim, victims of disablist hate crime would appear to be a perfect fit for gaining policy and societal attention. In his seminal piece he details particular attributes necessary for the construction of ideal victim status. These include: i) being weak; ii) carrying out a respectable project; iii) being without blame; iv) the offender is big and bad; v) the offender is unknown to the victim and vi) the victim is powerful enough to be heard but not too powerful so as to threaten 'countervailing interests' (Christie, 1986: 19-21). Such a typology speaks to original conceptions of victimology in terms of victim precipitation and proneness. But Christie is not making a moral judgment on the validity of the victim status, instead he is just pointing towards a particular social construction. Importantly, this is not a static notion because people can become ideal victims as they (or society) change. In this brief synopsis, the predicament of disabled victims of hate crime appears to be a good fit for his ideal victim thesis. They represent members of society who are perceived as being weaker (generally, and in comparison to their perpetrators), blameless (for their state of being and victim status) and for whom the offender might be unknown in many cases. Similarly, they lack the power to be a threat to the established order. 
However, this surface level analysis belies a deeper structural problem in the recognition of victims of disablist hate crime as legitimate hate crime victims; this will be examined in this chapter which expands upon Christie's piece by looking at the specific problems faced by victims who are not perceived as 'ideal' in several respects. By using the example of disability as a case study, I illustrate how 'ideal victims' need to be understood in the context of specific policy domains. In this regard, the hate crime discourse presents a useful example of the ways in which ideal victim groups are constructed through the process of policy formation. 'Hate crime' is the ultimate 'ideal victim' crime in that legislative approaches have specified very particular groups of victims as worthy of the enhanced protection that such laws afford. However, within this construction there are more complicated attributes than Christie could have envisaged. Through an analysis of these, I aim to demonstrate that disabled victims of hate crime are perceived as inherently vulnerable and prone to victimisation, thereby ironically rendering them invisible in hate crime approaches (which proves redundant in attempting to enhance this construction of vulnerability further). Therefore, the chapter discusses the benefits and limitations of 'ideal victim' status for victims of disablist hate crime, and the sacrifices that must be made in this quest for recognition.

\section{Constructing hate crime policy}

Hate crime policies have become a common feature of many Western governments in recent decades. They have enabled states to send a positive message about values of tolerance and diversity to society generally and to minority groups specifically; particularly those who have been subject to victimisation. Although the exact wording and definitions of these policies differs in scope (both across strands and jurisdictions where they exist), they do share some features of note. First, they stipulate which forms of criminality will be recognised, for example assault, murder or criminal damage. Second, they tend to attach an enhanced criminal sanction in the form of an extended punishment. This is the declaratory function of hate crime laws and allows governments to demonstrate their tougher stance on certain crimes. Third, and the main focus of this chapter, they determine which groups of victims will be afforded said protections. The decision over which groups are included in hate crime laws can be understood in the context of the rising significance of identity politics and mobilising of different social movements seeking legal recognition. This has been informed by 
various civil rights campaigns, feminist efforts and other victims' rights groups; as a result, hate crime policy generally includes groups who have experienced a history of oppression and have gathered empirical evidence to demonstrate and document their experiences. Gail Mason adds that they also need to have made a moral or emotional claim and a consideration of 'what these victim groups can do for the moral force of the law' (Mason, 2013: 79). This in turn has led to claims of a victim 'hierarchy', where groups excluded from hate crime policy - or to whom hate crime resources are not appropriately utilised - feel disenfranchised. For example, groups such as the homeless are routinely targeted as victims of violence and prejudice but not afforded the protection of hate crime policy. Therefore, in order to be included in hate crime policy, victims must not only possess particular identity attributes for inclusion in recognised groups, but such groups need to be sufficiently cared about or influential to win over relevant policy makers.

The rolling implementation of hate crime laws in Great Britain evidences this hierarchy somewhat. The UK has seen the steady advent and expansion of hate crime policy over the last twenty years. Mirroring developments in the United States, the initial legislative developments were framed with race as the first category enshrined in law. In Britain came about as a result of the racist murder of black teenager Stephen Lawrence in 1993, which prompted the New Labour government to enact a manifesto commitment to make racist violence a specific offence attracting an enhanced punishment (which they later did in 1997 after winning the general election). Religion was subsequently added as another category in 2001 after concerns about rising levels of Islamophobia in the UK following the 9/11 terror attacks in the United States.

In this early formation it is noteworthy that cases of 'stranger danger' came to be predominantly associated with notions and definitions of hate crime, in that it was possible to determine the motive as the perpetrator did not have any other reason for the attack (Mason, 2005). The prejudicial motive - the 'hate' for a person's identity was determined to be what had caused the crime and thus warranted harsher than usual punishment. As such, key cases such as that of Stephen Lawrence (and, in 2005, Anthony Walker - a black teenager murdered in Liverpool) came to be seen as archetypal hate crimes as a result of the attacks being committed by strangers to the victims. The connections here with Christie's ideal victim typology - in that the image of the stranger is a key tenet - appear evident. However, if race and religion formed 
the foundation of hate crime categories, and stranger violence the style in which this occurred, then the place of disability within provisions has been much more precarious.

Writing ahead of changes to include other forms of identity within hate crime frameworks, Jenness and Grattet (2001) described disability as part of a 'second tier' of provisions which - at the time - was seen to potentially include sexual orientation, gender and age as similar categories. Unlike racially and religiously motivated offences, evidencing prejudice in crimes against these groups warranted harder work to gather the required empirical evidence needed to convince policymakers that hate crime definitions should extend to include them. Disability has now been included in the USA, UK (since 2003) and eight other Organization for Security and Co-operation in Europe (OSCE) countries. Inclusion in law is a start, but there is evidence to suggest that it has not been embraced to the fullest extent in terms of implementation. In 2015/2016 the Crown Prosecution Service (CPS) in England and Wales completed 15,442 hate crime prosecutions. Of those, 941 were for disability hate crime; $75 \%$ resulted in a conviction which was around $8 \%$ lower than for other forms of hate crime. A further disparity was the extent to which Judges imposed a sentence uplift for cases of disability hate crime. This was only used in $11.9 \%$ of cases, compared with $37.8 \%$ for homophobic/transphobic and $34.8 \%$ in cases of racially or religiously aggravated crimes (CPS, 2016). Recent policy reviews admit that disability lags behind other hate crime victim groups in terms of reporting, service provision and appropriate protection (Justice Inspectorate, 2015). Despite policy attention now being paid to disablist hate crimes, they remain 'cellophane crimes' in that 'people walk right through them, look right through them, and never know they are there' (Sherry, 2002: 1).

A key theme running throughout the literature on victims of disablist hate crime is the extent to which they are viewed not as victims of hostility, but as victims of their inherent vulnerability. As Roulstone and Sadique (2013) note, there exists an assumption that disabled people are easy targets. This is borne partly from a history of medical models around disability but also previous policy which has sought to utilise a social care rather than criminal justice response. Disabled people have needed to be 'protected' from themselves, from society and from the dangerous criminal 'other'. This means that - within a hate crimes framework - rather than being embraced within the identity politics demand for a greater legal recognition of prejudice-motivated 
crimes, disabled people have instead been included as a result of wider social policies seeking enhanced safeguarding measures. In other words, the rhetoric surrounding disablist hate crime was more about promoting victim protection than punishing offender prejudice. Relating disablist hate crime to Christie's model, the 'ideal victim' relies upon understanding how the victim is constructed in relation to particular policies. Hate crime policy has developed in a specific way: around key 'figurehead cases' (those which tend to attract a high level of media attention), relating to 'stranger danger', reflecting campaigners' efforts, demarcating groups worthy of protection etc. While an initial viewing of disabled hate crime victims might see them fit within the typology that Christie puts forward, considering this in conjunction with hate crime policy paints a much more complex picture. This analysis will now move on to a more detailed analysis of each attribute that Christie details in order to demonstrate this complexity.

\section{The Victim's Weakness}

Christie's first attribute is that the victim is weak. He stipulates that the 'sick, old or very young are particularly well suited as ideal victims' (p19). Furthermore, this weakness is particularly relative to the strength of the offender. Christie is not more specific about why this weakness is significant, but one might infer that this is because, a) there might be increased harm and fear caused when a victim is weaker; and, b) it makes the criminal act more serious because they are selecting an easy target. Victims of disablist hate crime might appear to be ideal victims in this regard, potentially lacking the physical or mental strength to defend themselves. As Hughes (2009) notes, this perception is based on an immediate visual appearance whereby the 'strong, wellformed, non-disabled, masculine body is the benchmark and against this benchmark a woman is found wanting and a disabled person - man or woman - is weak and vulnerable'. Popular discourse around disabled people has often portrayed them as having a 'spoiled identity' and as facing stigma and abuse relating to their disability (Simcock and Castle, 2016: 19). As such they might be viewed as being weaker than the 'normal' (i.e. non-disabled) population. However, when examining the hate crime domain there are further complicating factors. Although disabled people might experience prejudice related to perceptions of their weakness, this is somewhat different from other hate crime victims. It is quite unusual for hate crime victims to be 
seen as inherently weaker than (their) perpetrators. If we examine the case of Stephen Lawrence, who was murdered in a racist attack, he was not portrayed as being weak. Instead, the focus is on the perpetrator's motive which, in turn, is about hostility towards the victim's identity.

In 2006, James Wheatley was jailed for 23 years for murdering Lee Irving, a mentally disabled man with learning difficulties. Wheatley repeatedly kicked and stamped on Lee in a number of attacks over nine days, eventually killing him. Three others were convicted for their role of helping to cover up the murder. Yet despite the police and Crown Prosecution Service submitting evidence that it was a disablist hate crime, the Judge dismissed this in his sentencing remarks:

"In my judgement you were motivated in his offence not by hostility towards those with disability but by your vicious and bullying nature which particularly takes advantage of those who are unable to or less able to resist." (Kennedy, 2016).

Irving's family disputed this perspective, arguing that it was a hate crime because of the dehumanising language that they used during the attack which was demonstrative of hostility based on disability. It appears that for 'ideal victims' of disability hate crime, being seen as weak suggests a crime of a different nature; one where victimisation has occurred as a result of being seen as an easy target rather than due to hostility towards the victim's identity. As such, this negates complexity of (the offender's) motive, which the ideal victim framework does not allow for in hate crime cases.

\section{Engagement in a Respectable Project}

The second attribute that Christie describes is arguably rather opaque. He states that victims should be carrying out a respectable project and gives the example of a woman caring for her sister. As a counter to this, he suggests the case of a young man who gets attacked whilst 'hanging around' in a bar and says that he is 'far from ideal' (p19). Van Wijk (2013: 163) suggests that in reality, the young man in the bar would be viewed rather neutrally in contemporary society and that a man about to commit a crime might be a more useful interpretation of someone doing a disrespectful project. Many hate crime victims - particularly those who receive public attention and sympathy - are described as being engaged in neutral or respectful activities either 
before or at the time of their attack. For example, much attention was paid to the Christian background of Stephen Lawrence's family and that he wanted to become an architect (Cottle, 2004). Similarly, Jody Dobrowski was a young gay man for whom 'life was good' and 'had everything to live for' when he was brutally murdered in a homophobic attack in London in 2005 (Foufas, 2015). Jody had been walking home from work and was set upon by two men who beat him so severely that he had to be identified by his fingerprints. Sentencing his killers to 28 years in prison, Judge Brian Barker noted that they had only one motive and that it was 'Jody's tragic misfortune to cross [their] path'. This interpretation of Christie's 'respectable project' suggests that the victims - who were going about their daily activities when attacked - would have otherwise had the potential to make a contribution to wider society.

For victims of disablist hate crime, there are unique factors linked to this aspect of the ideal victim typology which make its application more complex. For a start, there is a long history of stereotyping the disabled and viewing their mere existence as problematic, wounded or monstrous (Butler, 2009). As Anne Novis notes 'negative stereotypes towards disabled people start before birth, via segregation into day centres, residential homes, special schools and specialist employment' (Novis, 2013: 121). As such their lives do not exist; they are devalued or seen as burdensome. The label of vulnerability, so readily applied in policy contexts, is also emblematic of the burden disabled people place on local services. Roulstone and Sadique points towards the various safeguarding schemes which could risk 'disabled people losing, rather than gaining independence' (Roulstone and Sadique, 2013: 32). Negatively perceiving disabled people as 'abject' in terms of societal norms and values in turn impacts on their being able to engage in 'respectable projects' (Thorneycroft and Asquith, 2017). Furthermore, recent popular discourse in the UK around Fit for Work schemes, coupled with cuts to Disability Living Allowance, fuel prejudices about disabled people being a drain on resources and therefore unlikely to be seen as carrying out any sort of respectable or worthwhile endeavours. The little old lady in Christie's example is depicted as caring for her sister, thereby making a contribution to society. In disability hate crimes, the victims are more likely to be considered the 'sister' in that they are being cared for. This means that within Christie's framework their value as contributors is questioned.

\section{Blamelessness}


Christie suggests that to be granted ideal victim status, victims must be blameless in what happened to them. If individuals have a more ambiguous status, then they are less likely to be seen as victims (Bouris, 2007). Van Wijk (2013: 164) invokes the 'just deserts' theory to explain why people need to believe that bad things only happen to bad people. This in turn generates empathy towards the innocent victim, who we care about and can see as deserving of our concern. Cases with these qualities tend to attract a high level of media attention, which Thorneycroft and Asquith (2017) refer to as 'figurehead crimes'. Often, the reporting emphasizes the victim's 'innocence' and 'normality' which renders them a sympathetic figure. The homophobic murder of Mathew Shepard in the United States is one such example they invoke to demonstrate the power of a figurehead crime. In this case, the murder, combined with a cultural shift towards increasing equality for gay people's rights, meant Mathew's case was afforded a lot of attention both in policy terms (resulting in legislative changes) and in the press.

For victims of disability hate crime, their liability for being victimised sometimes lies in their gullibility. In 2006, Kevin Davies, a young man with epilepsy was murdered by three people who called themselves his friends. They had taken advantage of Kevin, forcing him to wear a dog collar and leash, stealing from him and abusing him over a period of time. Kevin was imprisoned by the group for 4 months before they killed him, yet when the perpetrators were convicted the judge described Kevin as being 'vulnerable, gullible and naïve' (Quarmby, 2011: 182). Similar themes have emerged in other cases. Brent Martin, who had learning difficulties, was killed by a group of young people who had befriended him in order to have him to carry out petty crimes on their behalf over a sustained period of time. On the night he was murdered, the group chased him through the streets, periodically assaulting Brent before finally beating him unconscious. The final blow was delivered to his prone body, whereupon they stripped him from the waist down to further humiliate Brent. At the trial, his family talked about how he had often been 'blamed for the misdeeds of others', as the judge again pointed out his gullibility at having been taken advantage of (Quarmby, 2011: 182).

Katharine Quarmby's analysis of disablist hate crime provides a detailed assessment of the many ways that targeted violence against disabled people has been ignored. She points out that disabled people have long been criminalised by the criminal justice 
system, so it is unsurprising that blame is apportioned to them. Aside from being naïve, Quarmby also notes the number of disabled people who are accused of being paedophiles and sex offenders, as in the aforementioned case of Bijam Ibrahimi. This pattern of false accusations for some disabled people creates an obscured image of them as potentially to blame for their victimisation and thus not able to embody Christie's required notion of 'blamelessness'.

\section{The Big and Bad Offender}

In Christie's typology, aspects of the offender's identity are stipulated which contribute towards perceptions of the victim's status. The (masculinised) offender is described as 'big and bad' in relation to the (feminised) weak and blameless victim. For hate crimes, the most exceptional and potentially straightforward cases tend to attract more attention in the popular media. This is because they play into the storyline narrative of an ideal crime, where there is no ambiguity about the offender's culpability. In addition, the idea that a person could be attacked purely because of a prejudice towards their identity underscores the offences as a particularly heinous and evil form of crime. Van Wijk notes that 'we have an intrinsic willingness to believe that people who commit such acts differ fundamentally from us' (2013: 165) and Christie's assertion that an ideal offender is 'a human being close to not being one' (p26). It is this 'evil' element - the intent - which hate crime legislation specifically recognises; perpetrators are considered to require harsher punishments as victims suffer more harm (Iganski, 2008).

For disablist hate crime, there are complicating factors surrounding the majority of offenders which makes it difficult to conceive of them as 'big and bad'. First, evidence suggests that the age profile of perpetrators is younger than for other forms of hate crime. Crown Prosecution Service data from 2015/16 showed that $19.6 \%$ of defendants were aged 18-24 years old, and 9.6\% were 14-17 years old. Most defendants in disablist hate crime cases were men (75.3\%), but there were a significantly higher proportion of women (24.5\%) compared to other strands of hate crime $(17.1 \%$ in racially and religiously aggravated hate crime and $16.5 \%$ in homophobic and transphobic hate crime) (CPS, 2017). In cases of disablist hate crime, while the actions taken may be particularly heinous, the offender(s) may not come 
across as such. Therefore, it is harder to discern a specific 'big and bad' offender who can be seen as evil and different from everyone else.

The case of Fiona Pilkington and her daughter Francecca Hardwick is an example of the difficulty in discerning offenders in disablist hate crime cases. Fiona and her daughter had endured years of abuse, much of which was directed towards Francecca who had a learning disability, from people described mostly as 'yobs' and 'youths' in media depictions of the case. Despite calling the police on no fewer than 38 occasions, no action was taken by the police, thus the harassment continued. Eventually, in 2007, Fiona drove herself and her daughter to a secluded area and set fire to the car, killing them both. The sustained nature and multitude of offenders involved in this case made discerning a clear motivation difficult. Nonetheless, a jury in the inquest found that the lack of police action and failure of local authorities to act had had a significant impact on Fiona's decision to take such drastic action (Quarmby, 2011). The failure of various institutions to respond appropriately to victims of hate crime means that they are effectively victimised again by the support services that let them down.

\section{The Unknown Offender}

Christie argues that an absence of any familiarity between victim and offender is a key attribute in granting ideal victim status. Specifically, there should be no prior personal relationship between victim and offender (p19). Christie does not specify why this is such a key attribute but given his other definitions one could infer that it is about the simplicity of motivation and ability not to assign any blame to the victim. Furthermore, the absence of information about the offender allows for the construction of $a$ 'dehumanized picture...the more foreign the better' (p29). This is in keeping with the early victimology literature which takes a positivist stance and looks to the image of the stranger as a being the ultimate 'baddy'. Similarly, a key criticism of hate crime as a concept has been that it has too readily relied upon images of the stranger which have perpetuated the idea that offences are rare and extraordinary. Kielinger and Stanko (2002: 5) suggested that this 'places the responsibility for the violence on strangers and therefore on individual rather than society as a whole'. In fact for many victims, experiences of hate crime are a daily, normal occurrence but when 'hatred intersects with the known we prefer to blame the social relationships of the known for fuelling the individual act of violence' (Stanko, 2001: 327). Nevertheless, high profile 
cases of hate crimes committed by offenders who were strangers to the victim have come to characterise everyday understandings about the nature of victimisation.

The relationship between victim and offender might therefore present a problem in attributing ideal victim status for many forms of hate crime. However, for victims of disablist hate crime, research suggests that this problem is more acute. Aside from the high proportion of victims who know the offender either as a neighbour or friend, they might also be a carer. In 2001, an undercover documentary broadcast by the BBC exposed a shocking regime of abuse of disabled residents in a private hospital called Winterbourne View. Secret footage had been captured of people being taunted, jeered at, dragged across the floor and abused. In his analysis, Chih Hoong Sin noted the shock that was expressed by politicians and the public alike and that in this case the criminal justice system did respond and prosecute the offenders for disablist hate crime (Sin, 2015 108). However, critics have argued that much of this abuse never reaches the courts because it happens in an institutional setting. This, combined with a perception that being a carer is a difficult and unskilled job with few rewards sometimes leads to a level of sympathy more directed towards the perpetrators. The isolation of a disabled person who relies upon their carer leads to a level of complexity which is difficult to square with the ideal victim concept.

A further particular phenomenon related to disabled victims is that of so-called 'mate crime'. Described by Pam Thomas (2013: 136) as 'hostile incidents carried out by one or more people the disabled person considers to be their friends or relatives', it is a particular feature of this strand of hate crime victims. Interpersonal relationships are often deliberately cultivated by the offenders to exploit the venerability that they see in the victim and also a lack of support structures in place to assist the disabled person (2013: 139). Raymond Atherton is an example of a disabled man who was 'befriended' in this way by a group of teenagers who would steal from him, eat his food and take his money. He had few people to tell about what was happening and said he would rather have the company of someone than no-one (Thomas, 2013: 143). It later emerged that many agencies with whom Raymond was in contact knew of the abuse; despite him moving house, the abuse continued up until the point of his eventual murder. His two young killers, aged 17 and 15 at the time were sentenced to 3 and a half years and 3 years in prison respectively (Quarmby, 2011: 103). In sum, the relationship between victim and offender in cases of disablist hate crime is seen as a 
complex mix of institutional and societal failings. The deliberate targeting is somehow different from the random attack the Christie envisages and one to which a level of understanding has to be extended to the perpetrators who might also have been failed by the system. Although this does not necessarily mean that offenders go unpunished, it does mean disabled victims are less likely to be seen as 'ideal' and for sentence enhancements to be used.

\section{Power and Influence}

The final attribute that Christie puts forward relates to the power and influence of victim groups in gaining ideal victim status. This is balanced by being weak enough not to be a threat to other interests (p21). In their examination of the construction of policy design, Schneider, Ingram and deLeon note that some groups have access and resources to influence and shape policy which allows them to be seen as worthy recipients of protection. This is about how groups are seen as having the right amount of sympathy and pity, the 'lack of political power sharply curtails their receipt of benefits...they do not have a strong role in the creation of national wealth, dependents are viewed as 'good' people but considerably less deserving of actual investments than advantaged people' (Schneider et al, 2014: 112). This is of particular relevance to hate crime policy, where critics have argued that a victim hierarchy has been created, precisely because of the reliance on campaign group activists in the construction of legislation. As the author found in previous research, a frustration for campaigners has been the extent to which policymakers rely upon them to gather evidence and push for legal recognition (Mason-Bish, 2010). The costs and manpower involved with this means that smaller and less well funded organisations struggle to have a role in the construction of hate crime policy and therefore, what ideal victims might look like.

As with the other victim attributes that Christie notes, research has demonstrated the difficulties for victims of disablist hate crime in establishing themselves as important enough to count. Similarly, smaller disabled people's organisations do not necessarily have direct access to government officials but have often relied upon larger charities who (arguably) had less involvement with victims themselves (Mason-Bish, 2010). In an age of budget cuts and with so many other social problems to deal with, it is unsurprising the disabled people's organisations have found it difficult to push for the 
adequate implementation of hate crime provisions. Anne Novis notes that this struggle was partly about being included in policy discussions but also in ensuring that they catered adequately for the needs of disabled people (Novis, 2013: 119).

A further point is the extent to which disabled victims evoke sufficient compassion and sympathy as to warrant a response. In her examination of emotions and hate crime law, Gail Mason suggests that this is essential because people must feel an obligation to resist prejudice against that group because 'familiarity breeds compassion' (Mason, 2013: 85). They need to possess the 'right amount of vulnerability, blamelessness and proximity to engender compassionate thinking' (p86). This can be about not having empirical credibility, being blameworthy or simply too different and strange to 'invite concern'. Disabled victims might therefore not meet the criteria of being viewed with enough sympathy because as we have seen they might be considered as partly to blame due to gullibility, or people may disbelieve the scale of the abuse they suffer. However, most potent is the claim that they are too strange, an argument supported by Thorneycroft and Asquith (2017). In their recent piece they query why so few cases of disablist hate crime achieve 'figurehead status', despite the undisputed horrors that disabled people have suffered. They suggest that it is because the victims are 'abject' in that their existence and bodies are deemed less than human. The narrative of social policy has been about detecting and treating disabled people for their conditions, proposing abortions or mercy killings for people deemed defective. Anne Novis argues that these messages are endorsed by government policies on benefit cuts which perpetuate a narrative that disabled people are a burden on the state (Novis, 2013: 119). The nature of hate crimes against disabled people often shows elements of this dehumanisation in the way that they are enslaved and tortured as being less than human (Quarmby, 2011).

\section{Constructing Deserving Victims}

This chapter has so far demonstrated the problems for victims of disablist hate crime in terms of gaining recognition using Christie's 'ideal victim' typology. I would now like to take this analysis further, by discussing the advantages of being an 'ideal victim' of hate crime. This is something about which Christie is rather ambiguous and he only implies what type of benefits a victim can expect to receive and that they may lead to calls for 'further measures' (p28). For hate crime, these measures include additional 
victim support and the potential to punish a perpetrator more harshly. However, as I have demonstrated, not all groups are treated equally and victims of disablist hate crime have struggled to be seen as 'ideal' in this context. Despite this, there are potential benefits for focusing on hate crime as a way to challenge perceptions of disability. As Chih Hoong Sin (2015: 101) notes, there has been an historic tendency to view disabled people as being at risk of violence because of their disability. This creates an inertia in policy responses which assume that the best outcome is to protect disabled people from the abuse that their disability causes. This notion of inherent vulnerability evokes negative and paternalistic assumptions which point towards a need to care for or treat disabled people instead of giving them full access to criminal justice responses. So although not seen as 'ideal' in Christie's formation it is worth challenging and contesting what could be described as the 'dominant culture's demeaning picture of the group' (Fraser, 2000,109). This speaks towards how in the construction of social problems, identity politics has often sought to have forms of violence recognised in very particular ways and as Barbara Perry has noted, 'rights claims embedded in hate crime legislation can be powerfully transformative discourses' (Perry, 2002: 488).

Furthermore, the ideas of vulnerability and presumed weakness are connected to medical models of disability tied to notions of biological pathology. Instead, being recognised as victims of hate crime rather than victims of disability offer a greater connection with issues of discrimination and structural inequality. As Tom Shakespeare notes 'The achievement of the disability movement has been to break the link between our bodies and our social situation and to focus on the real cause of disability, i.e. discrimination and prejudice' (1992: 40). So to be seen as worthy of protection in hate crime policy is to counter the fixation on inherent vulnerability which could lead to suggestions that disabled people are less than full human beings and so less worthy of full citizenship rights (Hughes, 2009). In the politics of recognition, it is better to be seen as an ideal victim of hate crime than an ideal victim of disability. This is why campaigners have been so vociferous in their assertion that disablism must be recognised 'correctly'.

\section{Concluding thoughts}


Christie's classic typology draws upon notions of weakness; blame; evil and stranger danger in order to demonstrate which groups of people are most likely to be given the legitimate status of 'ideal victim'. In this chapter I have applied the typology to victims of disablist hate crime. In doing so, I have demonstrated that it is necessary to understand his work within a particular policy context as legislation is framed around constructions of crime which might have their own attributes. In itself the case study of hate crime is an interesting one. It takes a particular policy response to victimisation and through social movement campaigns and policymaking efforts has created a specific set of deserving and undeserving victims. Many groups - older people, the homeless, sex workers - have not fitted with the general ideal victim typology and so have been left outside of policy efforts. Others - such as disabled people have been included but have had problems having policy implemented. I argue here that this is because of the clash of ideal victims generally and the construction of ideal victims in specific policy. For hate crime, we have seen a concept emerge which has often relied upon notions of stranger danger; of simple motivations and of victim blamelessness. These have been relayed to the public through the media to garner support. However, disability has had a more difficult journey in that victims are seen as less sympathetic and more complicated to be 'true' hate crime victims. This has meant that the benefits of being an ideal victim in terms of sentence enhancement and victim support have often been lacking. Worse than this, it has meant that 'endemic low aspirations for such groups lead to fatalistic acceptance that disabled people cannot expect anything different' (Sin, 2015: 101)

The examination of disabled victims also leads us towards some unpalatable truths. The historic treatment of disabled people has focused on medical concerns around the pathological body. Policy has tended to see the disability as the offender, the 'thing' that causes the problems and limitations. Disabled people are victims of their disability rather than attitudes and discrimination. As such issues of gullibility have often been used to excuse victimisation, with often a reliance on blaming a lack of treatment or appropriate care rather than encouraging access to justice. This 'disagnostic overshadowing' (Sin, 2015) is further complicated by the 'abject' nature of disabled people that renders them invisible to the criminal justice system. The ideal victim typology reminds us of the need to challenge popular discourse around victims of crime. The justice system is slowly acknowledging the specific nature of the victim 
experience and has published guidance which recognises the phenomenon of 'mate crime', the problems of assumed vulnerability and the role of society in challenging this. Campaigners feel that they are being heard more by policymakers (Novis, 2013; Brookes, 2013). However, we have to acknowledge our own role in the construction of ideal victims and the extent to which we accept or challenge these ideas.

\section{Reference List}

Bouris, E, (2007) Complex Political Victims, Bloomfield: Kumarian Press.

Brookes, S. (2013) 'A case for engagement: the role of the UK Disability Hate Crime Network' in A. Roulstone and H.Mason-Bish (eds) Disability, Hate Crime and Violence, London: Routledge, pp126-134.

Christie, N. (1986) 'The Ideal Victim' in E.A. Fattah (ed) From Crime Policy to Victim Policy: Reorienting the Justice System. Basingstoke : Macmillan pp17-30.

Cottle, S. (2004) The Racist Murder of Stephen Lawrence: Media Performance and Public Transformation, Westport, Conn: Praeger

Crown Prosecution Service (2016) CPS Hate Crime report, London: Crown.

Equality and Human Rights Commission (2011) Hidden in Plain Sight, London: EHRC.

Foufas, C. (2015) 'Why Jody Dobrowski is a name we must never forget,' Telegraph, 16 October. Available at: http://www.telegraph.co.uk/men/thinkingman/11934107Mhy-Jody-Dobrowski-is-a-name-we-must-never-forget.html (Accessed 9 May 2017).

Fraser, N. (2000) "Rethinking Recognition", in New Left Review vol 3, May-June, pp107-120.

Home Office. (2016) Hate Crime, England and Wales, 2015/16 Statistical Bulletin, London: Crown.

Hughes, B. (2009) 'Wounded/Monstrous/Abject: A critique of the disabled body in the sociological imaginary', Disability and Society, 24(4): 399-410.

Jenness, V. and Grattet, R. (2001) 'Examining the Boundaries of hate crime law: Disabilities and the 'Dilemma of Difference", Journal of Criminal Law and Criminology, 91: pp653-98.

Justice Inspectorate (2015) Joint Review of Disability Hate Crime, London: Crown. Kennedy, R. (2016) 'Lee Irving murder: Judge brands killer a 'vicious bully and a coward' as he is jailed for life', Chronicle Live, 2 December. Available at: 
http://www.chroniclelive.co.uk/news/north-east-news/lee-irving-murderer-jameswheatley-12264798 (Accessed 9 May 2017).

Kielinger, V. and Stanko, E. (2002) 'What can we Learn from People's Use of the Police?' in 'Hate Crimes', Criminal Justice Matters, 48:4-5.

Levin, J. (2013) 'Disablist Violence in the US: Unacknowledged crime', in A. Roulstone and H.Mason-Bish (eds) Disability, Hate Crime and Violence, London: Routledge, pp95-105.

Mason, G. (2005) 'Hate Crime and the Image of the Stranger', British Journal of Criminology, 45(6) pp 837-59.

Mason. G. (2013) 'The symbolic purpose of hate crime law: Ideal victims and emotion', Theoretical Criminology, 18(1) 75-92.

Mason-Bish, H. (2010) 'Future Challenges for Hate Crime Policy: Lessons from the Past, in N. Chakraborti (ed) Hate Crime: Concepts, Policy, Future Directions, Cullompton: Willan, pp58-77.

Novis, A. (2013) 'Disability Hate Crime: A Campaign Perspective', in A. Roulstone and H.Mason-Bish (eds) Disability, Hate Crime and Violence, London: Routledge, pp118-125.

Peachey, P. (2015) 'Bijan Embrahimi Murder: Man Killed by Lynch Mob Pleaded with Police for Help', Independent, 21 December. Available at:

http://www.independent.co.uk/news/uk/crime/bijan-ebrahimi-murder-man-killed-bylynch-mob-pleaded-with-police-for-help-a6782266.html (Accessed 9 May 2017)

Perry, B. (2002) 'Hate Crimes and Identity Politics', Theoretical Criminology, 6(4): pp485-502.

Quarmby, K. (2011) Scapegoat: Why We are Failing Disabled People, London: Portobello.

Roulstone, A. and Sadique, K. (2013) 'Vulnerable to Misinterpretation: Disabled People, 'vulnerability', hate crime and the fight for legal recognition', in A. Roulstone and H.Mason-Bish (eds) Disability, Hate Crime and Violence, London: Routledge, pp 25-39.

Schneider, A., Ingram, H. and deLeon, P. (2014) 'Democratic Policy Design: Scoial Constructions of Target Populations, in P. Sabatier and C. Weible (eds) Theories of the Policy Process, $3^{\text {rd }}$ Edition, Westview Press, pp105-150

Scope (2008) Getting Away With Murder, London: Scope.

Shakespeare, T. (1992) 'A response to Liz Crow', Coalition (September) 
Sherry, M. (2002) 'Don't Ask, Tell or Respond: Silent Acceptance of Disability Hate Crimes', Paper presented at the Ed Roberts Post Doctoral Fellowship in Disability Studies at the University of Califoria at Berkley Public Lecture Series 21 November.

Sherry, M. (2010) Disability Hate Crimes: Does anyone really hate the disabled? London: Routledge.

Simcock, P. and Castle, R. (2016) Social Work and Disability, Cambridge: Polity Press.

Sin, CH. (2015) 'Using a layers of influence model to understand the interaction of research, policy and practice in relation to disablist hate crime', in N. Chakraborti and J.Garland (eds) Responding to Hate Crime: The Case for Connecting Policy and Research, London: Policy Press.

Stanko, E. (2001) "Re-conceptualising the policing of Hatred: confessions and worrying dilemmas of a consultant", in Moran, Leslie. (ed) (2001) "Hate crimes: Critical Reflections", Special Edition of Law and Critique, vol 12, no 13, pp309-29.

Thomas, P. (2013) 'Hate crime or mate crime? Disablity hostility, contempt and ridicule', in A. Roulstone and H.Mason-Bish (eds) Disability, Hate Crime and Violence, London: Routledge, pp135-146.

Thorneycroft, R. and Asquith, N. (2017) "Figurehead' hate crime cases: developing a framework for understanding and exposing the 'problem' with 'disability", Continuum: Journal of Media and Cultural Studies, 31(3): 482-94.

Van Wijk, J. (2013) 'Who is the 'little old lady' of international crimes? Nils Christie's concept of the ideal victim reinterpreted, International Review of Victimology, 19(2): 159-79. 